\title{
Softening effect of Ikpiru and Yanyanku, two traditional additives used for the fermentation of African Locust Bean (Parkia biglobosa) seeds in Benin
}

\author{
Pélagie Bidossessi AGBOBATINKPO, Sylvain Déley DABADÉ, Fabrice LALEYÈ, \\ Noèl AKISSOE, Paulin AZOKPOTA and Joseph Djidjoho HOUNHOUIGAN *
}

\author{
Département de Nutrition et Sciences Alimentaires, Faculté des Sciences Agronomiques, \\ Université d'Abomey-Calavi, Cotonou, Benin. \\ *Corresponding author, Email: joseph.hounhouigan@gmail.com
}

\begin{abstract}
Ikpiru and Yanyanku are two additives used for the traditional alkaline fermentation of African locust bean (Parkia biglobosa. Benth) to produce food condiments in Benin. In this study, African locust beans (Parkia biglobosa. Benth) were fermented with or without Ikpiru and Yanyanku to assess the factors explaining the softening role of these additives during the fermentation process. Changes in microbial population, chemical components and texture parameters of the fermented cotyledons were determined during the fermentation process. Bacillus spp. predominated during the fermentation, with an upward trend. The use of Yanyanku or Ikpiru seems to increase Bacillus count during the earlier stage (between 0 and 18 hours) of fermentation, since the variations were $35 \%$ and $43 \%$ (growth rate of 0.13 and $0.16 \log _{10} \mathrm{~h}^{-1}$ ) for trial with Yanyanku and Ikpiru respectively, versus $6 \%\left(0.02 \log _{10} \mathrm{~h}^{-1}\right)$ for the control. Despite this initial gap, the final count (after $48 \mathrm{~h}$ ) did not show any significant difference between the control and samples with additives. Compressing forces were significantly lower between 12 to $24 \mathrm{~h}$ for cotyledons fermented with additives than for the control, suggesting a rapid disintegration, i.e., the softening effect of Yanyanku and Ikpiru during the fermentation of African locust bean seeds. No significant difference ( $p>0.05$ ) was observed between proximate composition of the samples fermented without additives and those fermented with additives.

(C) 2012 International Formulae Group. All rights reserved.
\end{abstract}

Keywords: Fermentation, Bacillus, softening effect, softening.

\section{INTRODUCTION}

Roselle (Hibiscus sabdariffa L.) is an herbal shrub plant which seeds are rich in nutritional components especially proteins, oil and dietary fibre (Ismail et al., 2008). Like other plant seeds, it is widely used for nutritional purposes such as food condiments or sauce ingredients. Products from alkaline fermentation of Hibiscus sabdariffa known as Bikalga (Burkina Faso), Dawadawa botso
(Niger), Datou (Mali), Furundu (Soudan) and Mbuja (Cameroon) are used directly as condiments for preparation of sauces (Parkouda et al., 2008). Yanyanku and Ikpiru are also fermented products from Hibiscus sabdariffa but used as additives for African locust bean seeds fermentation to produce Sonru and Iru, two food condiments used in Benin (Azokpota et al., 2006; Agbobatinkpo et al., 2011). Indeed, these additives are 
widely used on the presumption that they favour the softening of the raw cotyledons. In Benin, Sonru, Iru and Afitin are main food condiments used to enhance the flavour of many dishes including soups and sauces (Gutierrez et al., 2000; Azokpota et al., 20006). Similar fermented condiments have been reported to be a good source of vitamin $\mathrm{B}_{2}$ (riboflavin) and vitamin $\mathrm{B}_{3}$ (niacin) (Sarkar and Tamang, 1998) and mineral elements such as iron, potassium, calcium, magnesium, sodium and zinc (Omafuvbe et al., 2000). In West Africa, the traditional fermentation of African locust beans has been reported to be uncontrolled and often associated with environmental microorganisms. Consequently, the quality of the products is highly variable ( Azokpota et al., 2006; Parkouda et al., 2008). Sometimes, fermentation can end in failure resulting in the loss of the end product. A major factor which could stabilize the quality of products from one production batch to another is the development and the use of starter cultures for controlled fermentation (Achi, 2005). Recent investigation reported that Yanyanku and Ikpiru play a role in the softening of African locust bean cotyledons during the fermentation of African locust beans to produce food condiments (Agbobatinkpo et al., 2011). This softening capability of Yanyanku and Ikpiru and their role as possible fermentation enhancers remain to be proved. This study aims at assessing the effect of Yanyanku and Ikpiru during the fermentation of African locust beans to produce local condiments.

\section{MATERIALS AND METHODS Materials}

African locust beans were bought in a local market at Natitingou, North West of Benin. The traditional additives Yanyanku and Ikpiru were collected from Parakou (Northern Benin) and Ketou (Southern Benin) respectively.

\section{Production and sampling of Sonru and Iru} Raw African locust beans (ALB) were boiled for 8 hours and left overnight in the boiling water, according to the traditional process (Azokpota et al., 2006). Cotyledons were extracted by washing beans and removing the seeds coat by rubbing boiled beans within the palms of the hand. The undehulled beans were sorted out. All the cotyledons obtained were divided into three parts. Each part of cotyledons was brought to boil for 10 minutes. Yanyanku and Ikpiru were added according to the traditional practice $(60 \mathrm{mg}$ of Yanyanku or Ikpiru (about $10^{6} \mathrm{cfu}$ of Bacillus) / $100 \mathrm{~g}$ of African locust beans) when the boiling point is reached (Agbobatinkpo et al., 2011). Yanyanku was added to obtain Sonru (trial with Yanyanku: WY) and Ikpiru for Iru (trial with Ikpiru: WI). The third part without any additive (trial without additives: WA) was used as control. After boiling for about $10 \mathrm{~min}$ more, the hot water was drained off immediately and the cotyledons was spread into 6 baskets (each basket corresponding to each sampling time), covered, wrapped with jute sack and let to ferment at room temperature $\left(25-28{ }^{\circ} \mathrm{C}\right)$ for $48 \mathrm{~h}$. The fermenting beans were sampled at $0,6,12,18,24$ and 48 hours for microbiological, chemical and texture analyses. The temperature of the fermented product was measured with thermometer (76 $\mathrm{mm}$ immersion, Brannan, UK) at each sampling time, as a quantitative variable. The experiment was carried out in duplicate.

\section{Microbiological analysis}

Ten grams of each sample were weighed aseptically and transferred into 90 $\mathrm{mL}$ sterile peptone-bacteriological salt solution (5 g peptone, $8.5 \mathrm{~g} \mathrm{NaCl}, 1000 \mathrm{~mL}$ distilled water, $\mathrm{pH} 7.0 \pm 0.2$ ) and homogenized for about one (1) minute using a stomacher (Stomacher 400 circulator Seward. England). Micro-organisms were enumerated by drop plate method (Herigstad et al., 2001). Aerobic mesophilic bacteria were grown on Plate Count Agar (PCA Oxoid, CM0463) incubated at $30{ }^{\circ} \mathrm{C}$ for 72 hours. Staphylococci were grown on Baird-Parker (BP. Oxoid, CM275) supplemented with 5\% steril egg yolk-tellurite emulsion (Oxoid, SR 54) incubated at $37{ }^{\circ} \mathrm{C}$ for 48 hours. Bacillus 
was grown on Nutrient Agar (Oxoid CM 0003) incubated at $30{ }^{\circ} \mathrm{C}$ for 72 hours. Bacillus spores occur in the highest concentration in different types of Yanyanku produced by different processors in Benin (Azokpota et al, 2011). Thus, to confirm the presence of Bacillus spores, cells were observed by microscopy (x 1000. ZEISS AXIOSTAR plus Germany).

Per $30 \mu 1$ seeding, numbers of colonies ranging between 30-90 were considered for calculation (Herigstad et al., 2001; Chadare et al., 2010). The number of micro-organisms was calculated according to Chadare et al. (2010).

\section{Physico-chemical and texture analyses}

Crude fat, crude protein and ash contents of samples were determined, using A.O.A.C methods 27.006, 27.007 and 27.009 respectively (A.O.A.C, 1984). The $\mathrm{pH}$ was measured according to Nout et al. (1989). The softness indices of fermented cotyledons were determined with uniaxial compression and penetration tests which were performed on cotyledons samples using a Stevens texture analyzer (Stevens-LFRA texture analyzer, Harlow. U.K.). Each cotyledon was compressed either with a cylindrical probe (Clear Plastic 35 mm long TA11, 1" diameter for compression) or with a conical probe (Clear Plastic $28 \mathrm{~mm}$ diameter TA16 for penetration) moving at $0.2 \mathrm{~mm} / \mathrm{s}$ over a total displacement of $2 \mathrm{~mm}$. The maximum compression and penetration forces were measured. Two replications were conducted for each batch and twelve measurements at each fermentation time.

\section{Statistical analysis}

Statistical analyses were performed with Statistica 7 (StatSoft. Tulsa. USA) using Anova and general linear model (GLM) procedures with temperature being quantitative variable. Newman-Keuls mean comparisons test (normality test positive) or Kruskal-Wallis test (normality test negative) were used.

\section{RESULTS \\ Changes in microorganisms during the fermentation of ALB with or without additives}

Table 1 shows aerobic mesophilic bacteria (AMB), Bacillus spp. and Staphylococcus spp. changes during the fermentation process with or without additives.

Aerobic mesophilic bacteria count significantly increased as fermentation progressed. They increased from $6.8 \log _{10}$ $\mathrm{cfu} / \mathrm{g}$ at the beginning of the fermentation to $9.9 \log _{10} \mathrm{cfu} / \mathrm{g}$ at 48 hours. In addition, significant effect of additives used and temperature in the batch were evidenced. Manova (General Linear Model analysis) revealed that the temperature (quantitative variable) during fermentation affected negatively the count. Indeed, the temperature recorded in the batch increased from $33{ }^{\circ} \mathrm{C}$ at the beginning $(0 \mathrm{~h})$ of fermentation to $44{ }^{\circ} \mathrm{C}$ at $18 \mathrm{~h}$ and decreased thereafter to $33{ }^{\circ} \mathrm{C}$ at the end $(48 \mathrm{~h})$ of the fermentation. Samples inoculated with Yanyanku had significantly higher count $\left(8.9 \log _{10} \mathrm{cfu} / \mathrm{g}\right)$ than the control (8.4 $\left.\log _{10} \mathrm{cfu} / \mathrm{g}\right)$, the latter being similar to the sample with Ikpiru (8.3 $\left.\log _{10} \mathrm{cfu} / \mathrm{g}\right)$.

As far as Bacillus count is concerned, no significant effect of additive was evidenced, with mean value ranging between 8.3-8.5 $\log _{10} \mathrm{cfu} / \mathrm{g}$. However, Bacillus count significantly increased with fermentation time from 7.1 at the beginning of the fermentation to $9.3 \log _{10} \mathrm{cfu} / \mathrm{g}$ at 48 hours, with the trend depending on additives. Batches fermented with Yanyanku reached maximum count of 9.2 $\log _{10} \mathrm{cfu} / \mathrm{g}$ at $12 \mathrm{~h}$ while those fermented with Ikpiru reached maximum $\left(9.5 \log _{10}\right.$ $\mathrm{cfu} / \mathrm{g}$ ) at $18 \mathrm{~h}$ fermentation. Bacillus spp. count of ALB fermented without additives (control) reached its highest level of 9.1 Log $10 \mathrm{cfu} / \mathrm{g}$ later at $24 \mathrm{~h}$ fermentation. Except for ALB fermented with Ikpiru at $48 \mathrm{~h}(9.5$ $\log _{10} \mathrm{cfu} / \mathrm{g}$ ), samples obtained at $24 \mathrm{~h}$ and 48 $\mathrm{h}$ had similar Bacillus spp. counts (8.9-9.2 $\left.\log _{10} \mathrm{cfu} / \mathrm{g}\right)(\mathrm{P}>0.05)$. Indeed, the changes in the Bacillus spp. seem to take place between 6 and $24 \mathrm{~h}$ of fermentation. Significant effect of additive was observed at 
$18 \mathrm{~h}$ of the fermentation, with the control (WA) being $8.3 \log _{10} \mathrm{cfu} / \mathrm{g}$, versus $9.5 \log 10$ cfu/g and 9.3 $\log _{10} \mathrm{cfu} / \mathrm{g}$ for samples WI and WY respectively $(\mathrm{P}<0.01)$. Moreover, at $18 \mathrm{~h}$ of fermentation, ALB cotyledons from fermentation without additives were more individualized and seemed to be less soft and less pasty than those from fermentation with additives. The use of Yanyanku or Ikpiru enhanced Bacillus count between 0 and 18 hours of fermentation, since the rate of growth (initial value) were 0.13 and $0.16 \log _{10} \mathrm{~h}^{-1}$ (35\% and $43 \%$ of variations) for WY and WI respectively, versus $0.02 \log _{10} \mathrm{~h}^{-1}$ (6\% of variation) for the control (WA).

With respect to Staphylococcus spp., no effect of additives was evidenced but their count significantly increased during the fermentation process. Staphylococcus count was around $3 \log _{10} \mathrm{cfu} / \mathrm{g}$ at the onset and 7.7 $\log _{10} \mathrm{cfu} / \mathrm{g}$ at $48 \mathrm{~h}$.

In short, Manova (General Linear Model analysis) revealed that microorganisms count varied significantly with the fermentation time but Bacillus count were essentially dependent on both fermentation time and additives.

\section{Effect of additives on the texture during the fermentation of ALB cotyledons}

Table 2 and Table 3 show the results of the texture measurement using either a cylinder probe for compression (Table 2) or a cone probe for penetration tests (Table 3). Analysis of variance evidenced significant effect of additives as well as fermentation time on the texture parameters of the ALB cotyledons.

Whatever the type of sample (fermented with additives and control), there was a drastical and significant decrease in maximum compression force of the ALB cotyledons with the fermentation time (Table 2). As far as the control is concerned, the maximum compression force at $0 \mathrm{~h}$ was $8.32 \mathrm{~N}$ versus $1.55 \mathrm{~N}$ and $0.35 \mathrm{~N}$ at $24 \mathrm{~h}$ and $48 \mathrm{~h}$ respectively. The same trend was observed with samples fermented with additives. In addition, from 12 to $24 \mathrm{~h}$ fermentation time, the cotyledons from samples fermented with additives (WY and WI) were significantly softer than those from samples fermented without additives. At $24 \mathrm{~h}$, the maximum compression force was $1.55 \mathrm{~N}$ for the control (WA) versus $0.58 \mathrm{~N}$ and $0.64 \mathrm{~N}$ for cotyledons fermented with Ikpiru (WI) and cotyledons fermented with Yanyanku (WY) respectively.

As far as the penetration force is concerned, General Linear Model analysis showed that additives used as well as fermentation time significantly affected African locust bean cotyledons texture during the fermentation. Indeed, African locust bean cotyledons firmness (penetration force) decreased as the fermentation progressed depending on additives used.

\section{Effect of additives on the physico-chemical composition during the fermentation of ALB cotyledons}

The $\mathrm{pH}$ values ranged between 6.2 and 8.0, the protein content between 34.9 and $39.2 \%$ (dry basis), the ash content varied from 2.5 to $3.2 \%$ (dry basis) and the fat content from 35 to $43.7 \%$ (dry basis).

The $\mathrm{pH}$ value, ash and fat contents of the fermented African locust beans had an upward trend during the fermentation period, whereas protein content a downward trend. Except for the $\mathrm{pH}$, no significant interaction effects of additives and fermentation time were evidenced for all others parameters ( $p$ > 0.05) (Table 4). In addition, no significant difference $(p>0.05)$ was observed between the $\mathrm{pH}$ of the samples fermented without additives and those fermented with additives, with $\mathrm{pH}$ values ranging between 7.1 and 7.3.

Irrespective of additives, protein content decreased from $39.2 \%(\mathrm{db})$ at $0 \mathrm{~h}$ to $35 \%(\mathrm{db})$ at $48 \mathrm{~h}$. Reversely, fat content increased with fermentation time, with values varying from $35.0 \%(\mathrm{db})$ at $0 \mathrm{~h}$ to $43.7 \%(\mathrm{db})$. Samples fermented with additives were similar to the control with $39.1 \%(\mathrm{db})$ of mean fat content.

With regard to ash content, values of $2.9 \%(\mathrm{db})$ were obtained at the end of fermentation ( $24 \mathrm{~h}$ and $48 \mathrm{~h}$ ) versus $2.6-2.7 \%$ $(\mathrm{db})$ at the earlier period of fermentation ( 0 to $18 \mathrm{~h})$. 
Correlations between compression force and physico-chemical parameters and microorganisms count

Some physico-chemical characteristics and microbial count were highly correlated to the compression force, an indicator of softening of the ALB (Figure 1). Thus, Bacillus ( $\mathrm{r}=-0.85)$ or Aerobic mesophilic Bacteria ( $\mathrm{r}=-0.92)$, Staphylococcus $(\mathrm{r}=-0.81)$ counts, the $\mathrm{pH}(\mathrm{r}=-0.91)$ and fat content $(\mathrm{r}=-$ $0.95)$ were significantly and negatively correlated with the compression force. Reversely, proteins content was positively correlated with this parameter $(r=0.84)$. No significant correlation was evidenced between the ash content and the compression force. These relations could tentatively explained factors involved in the softening of ALB. However, further and future research will clarify the mechanism and factors responsible of the softening of ALB during fermentation.

Table 1: Effect of additives and fermentation duration on micro organisms counts.

\begin{tabular}{lcccc}
\hline Times (Hours) & Additives & $\begin{array}{c}\text { Bacillus } \\
\text { (Log cfu/g) }\end{array}$ & $\begin{array}{c}\text { AMB } \\
\text { (Log cfu/g) }\end{array}$ & $\begin{array}{c}\text { Staphylococcus } \\
\text { (Log cfu/g) }\end{array}$ \\
\hline 0 & WA & 7.81 & 6.94 & 2.35 \\
0 & WI & 6.61 & 6.39 & 2.52 \\
0 & WY & 6.86 & 7.19 & 4.16 \\
6 & WA & 7.84 & 7.38 & 5.02 \\
6 & WI & 7.49 & 6.57 & 5.14 \\
6 & WY & 7.48 & 7.71 & 5.24 \\
12 & WA & 8.47 & 8.51 & 7.27 \\
12 & WI & 7.89 & 8.77 & 6.85 \\
12 & WY & 9.20 & 8.35 & 6.35 \\
18 & WA & 8.28 & 8.95 & 7.10 \\
18 & WI & 9.49 & 8.88 & 6.84 \\
18 & WY & 9.27 & 10.08 & 7.43 \\
24 & WA & 8.92 & 8.79 & 7.17 \\
24 & WI & 9.09 & 9.36 & 6.60 \\
24 & WY & 9.19 & 9.69 & 7.82 \\
48 & WA & 9.09 & 9.83 & 7.76 \\
48 & WI & 9.47 & 9.79 & 7.32 \\
48 & WY & 9.21 & 10.13 & 8.05 \\
Temperature & & NS & $* *$ & NS \\
Times & & $* *$ & $* *$ & $*$ \\
Additives & & NS & $*$ & NS \\
Times*Additives & & $* .09$ & NS & NS \\
Residual Standard Deviation & 0.09 & 0.16 \\
\hline WA S & & & \\
\hline
\end{tabular}

WA: Samples from fermentation without additives; WY: Samples from fermentation with Yanyanku; WI: Samples from fermentation with Ikpiru; *: significant $(\mathrm{P}<0.05)$, **: Highly significant $(\mathrm{P}<0.01)$, NS: Not significant $(\mathrm{P}>0.05)$ 
Table 2: Changes in maximum Compression Force of ALB fermented cotyledons with or without additives $(\mathrm{N})$.

\begin{tabular}{|c|c|c|c|c|}
\hline $\begin{array}{l}\text { Fermentation } \\
\text { time (Hours) }\end{array}$ & $\begin{array}{c}\text { ALB } \\
\text { fermented } \\
\text { without } \\
\text { Additives }\end{array}$ & $\begin{array}{c}\text { ALB } \\
\text { fermented with } \\
\text { Ikpiru }\end{array}$ & $\begin{array}{c}\text { ALB } \\
\text { fermented with } \\
\text { Yanyanku }\end{array}$ & Mean \\
\hline 0 & $8.32 \mathrm{a}^{1}$ & $8.34 \mathrm{a}^{1}$ & $8.80 \mathrm{a}^{1}$ & $\begin{array}{l}8.59 \mathrm{~A} \\
(0.35)\end{array}$ \\
\hline 6 & $8.65 \mathrm{a}^{1}$ & $8.55 \mathrm{a}^{1}$ & $8.45 \mathrm{a}^{1}$ & $8.49 \mathrm{~A}(0.27)$ \\
\hline 12 & $6.49 \mathrm{~b}^{1}$ & $3.81 \mathrm{~b}^{2}$ & $6.07 b^{3}$ & $5.46 \mathrm{~B}(1.70)$ \\
\hline 18 & $3.46 \mathrm{c}^{1}$ & $1.58 \mathrm{c}^{2}$ & $2.19 c^{3}$ & $2.42 \mathrm{C}(1.18)$ \\
\hline 24 & $1.55 \mathrm{~d}^{1}$ & $0.58 \mathrm{~d}^{2}$ & $0.64 \mathrm{~d}^{2}$ & $0.95 \mathrm{D}(0.56)$ \\
\hline 48 & $0.35 \mathrm{e}^{1}$ & $0.24 \mathrm{~d}^{1}$ & $0.05 \mathrm{~d}^{1}$ & $0.21 \mathrm{E}(0.14)$ \\
\hline Mean & $4.67^{1}(3.40)$ & $3.95^{2}(3.52)$ & $4.37^{1}(3.64)$ & \\
\hline $\begin{array}{l}\text { Residual } \\
\text { Standard } \\
\text { Deviation } \\
\text { (RSD) }\end{array}$ & \multicolumn{4}{|c|}{0.07} \\
\hline Times & \multicolumn{4}{|c|}{$\mathrm{S}$} \\
\hline Additives & \multicolumn{4}{|c|}{$S$} \\
\hline Times $*$ & \multirow{2}{*}{\multicolumn{4}{|c|}{$S$}} \\
\hline Additives & & & & \\
\hline
\end{tabular}

\section{DISCUSSION}

The use of Yanyanku and Ikpiru increased Bacillus count during the earlier stage (between 0 and 18 hours) of fermentation, with a significant effect at $18 \mathrm{~h}$. The few hours delay in showing significant effect of additive on Bacillus count (at $18 \mathrm{~h}$ ) can be explained taking into account that Bacillus spores predominated in such a product as pointed out by Parkouda et al. (2008) for Bikalga and for Yanyanku and Ikpiru (Agbobatinkpo et al., 2011). Indeed, Bacillus in the spore form is activated by the previous heating of the mixture of additives and cotyledons before fermentation. So, development of spores into vegetative cells can take time. Accordingly, Sneath et al.
(1986) observed that the transformation of a dormant endospore into a Bacillus vegetative cell usually involves three sequential processes including activation (heat treatment for 10-30 $\mathrm{min}$ ), a germination (the duration depending on environmental conditions and the species or strain) and an outgrowth (only in a medium that can support cell growth). In our case (after heating), a minimum of $12 \mathrm{~h}$ of fermentation, were probably necessary for initiating Bacillus endospores germination. Then, 12 to $18 \mathrm{~h}$ of fermentation was probably suitable for Bacillus endospores for completing germination and outgrowth, with a significantly higher count at $18 \mathrm{~h}$ of fermentation for both additives (WY and WI). 
Table 3: Changes in maximum penetration Force of ALB fermented cotyledons with or without additives $(\mathrm{N})$.

\begin{tabular}{|c|c|c|c|c|}
\hline \multirow{3}{*}{$\begin{array}{l}\text { Fermentation time } \\
\text { (Hours) }\end{array}$} & \multirow{3}{*}{$\begin{array}{l}\text { ALB fermented } \\
\text { without Additives }\end{array}$} & \multicolumn{2}{|c|}{ ALB fermented with additives } & \multirow[t]{3}{*}{ Mean } \\
\hline & & \multirow[b]{2}{*}{$\begin{array}{l}\text { ALB fermented } \\
\text { with Ikpiru }\end{array}$} & & \\
\hline & & & $\begin{array}{l}\text { ALB fermented } \\
\text { with Yanyanku }\end{array}$ & \\
\hline 0 & $1.85 \mathrm{a}^{1}$ & $1.81 \mathrm{a}^{1}$ & $1.79 \mathrm{a}^{1}$ & $1.81 \mathrm{~A}(0.06)$ \\
\hline 6 & $1.40 \mathrm{~b}^{1}$ & $1.17 \mathrm{c}^{2}$ & $1.51 \mathrm{~b}^{1}$ & $1.36 \mathrm{~B}(0.22)$ \\
\hline 12 & $0.92 \mathrm{~d}^{1}$ & $0.82 \mathrm{~d}^{1}$ & $0.80 \mathrm{~d}^{1}$ & $0.84 \mathrm{C}(0.14)$ \\
\hline 18 & $0.66 \mathrm{e}^{1}$ & $0.28 \mathrm{f}^{2}$ & $0.32 \mathrm{f}^{2}$ & $0.41 \mathrm{D}(0.21)$ \\
\hline 24 & $0.33 \mathrm{f}^{1}$ & $0.31 \mathrm{f}^{1}$ & $0.39 \mathrm{f}^{1}$ & $0.35 \mathrm{D}(0.08)$ \\
\hline 48 & $0.07 \mathrm{~g}^{1}$ & $0.06 \mathrm{~g}^{1}$ & $0.06 \mathrm{~g}^{1}$ & $0.06 \mathrm{E}(0.02)$ \\
\hline Mean & $0.84^{1}(0.63)$ & $0.75^{2}(0.63)$ & $0.81^{2}(0.65)$ & \\
\hline Residual Standard & & & & \\
\hline Deviation & \multicolumn{4}{|c|}{0.01} \\
\hline Times & \multicolumn{4}{|c|}{ S } \\
\hline Additives & \multicolumn{4}{|c|}{$\mathrm{S}$} \\
\hline Times*additives & \multicolumn{4}{|c|}{ S } \\
\hline
\end{tabular}


Table 4: Physico-chemical changes during the fermentation of African locust bean seeds with and without additives.

\begin{tabular}{lccccc}
\hline Fermentation time (Hours) & ALB fermented seeds & pH & Ash (\%) & Protein (\%) & Fat (\%) \\
\hline 0 & Without additives (WA) & $6.5 \pm 0.6 \mathrm{ab}$ & $2.5 \pm 0.2 \mathrm{a}$ & $39.1 \pm 0.2 \mathrm{a}$ & $35.5 \pm 1.1 \mathrm{a}$ \\
& With Ikpiru & $7.0 \pm 0.0 \mathrm{a}$ & $2.6 \pm 0.6 \mathrm{a}$ & $39.4 \pm 0.7 \mathrm{a}$ & $35.7 \pm 0.3 \mathrm{a}$ \\
& With Yanyanku & $6.2 \pm 0.2 \mathrm{~b}$ & $2.6 \pm 0.2 \mathrm{a}$ & $39.0 \pm 0.4 \mathrm{a}$ & $33.7 \pm 1.5 \mathrm{a}$ \\
6 & WA & $6.8 \pm 0.9 \mathrm{a}$ & $2.8 \pm 1.3 \mathrm{a}$ & $38.6 \pm 0.4 \mathrm{a}$ & $35.6 \pm 1.6 \mathrm{a}$ \\
& With Ikpiru & $7.0 \pm 0.0 \mathrm{a}$ & $2.8 \pm 1.0 \mathrm{a}$ & $38.7 \pm 0.1 \mathrm{a}$ & $35.2 \pm 0.3 \mathrm{a}$ \\
& With Yanyanku & $6.2 \pm 0.1 \mathrm{a}$ & $2.4 \pm 0.0 \mathrm{a}$ & $38.6 \pm 0.2 \mathrm{a}$ & $34.5 \pm 1.0 \mathrm{a}$ \\
12 & WA & $6.7 \pm 0.2 \mathrm{a}$ & $2.9 \pm 0.4 \mathrm{a}$ & $37.3 \pm 0.9 \mathrm{a}$ & $39 \pm 1.4 \mathrm{a}$ \\
& With Ikpiru & $7.0 \pm 0.0 \mathrm{a}$ & $2.8 \pm 0.3 \mathrm{a}$ & $37.7 \pm 0.8 \mathrm{a}$ & $38.9 \pm 2.5 \mathrm{a}$ \\
& With Yanyanku & $7.0 \pm 0.3 \mathrm{a}$ & $2.6 \pm 0.1 \mathrm{a}$ & $37.3 \pm 0.8 \mathrm{a}$ & $37.6 \pm 6 \mathrm{a}$ \\
18 & WA & $7.4 \pm 0.2 \mathrm{a}$ & $2.6 \pm 0.3 \mathrm{a}$ & $36.9 \pm 0.4 \mathrm{a}$ & $39.7 \pm 1.0 \mathrm{a}$ \\
& With Ikpiru & $7.5 \pm 0.0 \mathrm{a}$ & $2.7 \pm 0.3 \mathrm{a}$ & $37.7 \pm 1.3 \mathrm{a}$ & $39.8 \pm 2.2 \mathrm{a}$ \\
& With Yanyanku & $7.9 \pm 0.1 \mathrm{~b}$ & $2.4 \pm 0.1 \mathrm{a}$ & $37 \pm 0.8 \mathrm{a}$ & $41 \pm 0.3 \mathrm{a}$ \\
24 & WA & $7.5 \pm 0.1 \mathrm{a}$ & $3.2 \pm 0.6 \mathrm{a}$ & $35.4 \pm 0.7 \mathrm{a}$ & $42.1 \pm 0.1 \mathrm{a}$ \\
& With Ikpiru & $7.5 \pm 0.1 \mathrm{a}$ & $3 \pm 0.4 \mathrm{a}$ & $36.9 \pm 1.1 \mathrm{~b}$ & $41.1 \pm 1.1 \mathrm{a}$ \\
& with Yanyanku & $7.9 \pm 0.1 \mathrm{~b}$ & $2.6 \pm 0.3 \mathrm{a}$ & $37.7 \pm 1.0 \mathrm{~b}$ & $42.6 \pm 0.4 \mathrm{a}$ \\
48 & WA & $8.0 \pm 0.1 \mathrm{a}$ & $3.2 \pm 0.5 \mathrm{a}$ & $35.1 \pm 0.5 \mathrm{a}$ & $43.5 \pm 0.4 \mathrm{a}$ \\
& With Ikpiru & $8.0 \pm 0.0 \mathrm{a}$ & $3 \pm 0.3 \mathrm{a}$ & $34.9 \pm 0.6 \mathrm{a}$ & $42.9 \pm 1.5 \mathrm{a}$ \\
& with Yanyanku & $8.0 \pm 0.1 \mathrm{a}$ & $2.6 \pm 0.3 \mathrm{a}$ & $35.1 \pm 0.9 \mathrm{a}$ & $44.6 \pm 0.9 \mathrm{a}$ \\
Residual Standard Deviation & & 0.03 & 0.04 & 0.09 & $\mathrm{~S}$ \\
Times & $\mathrm{S}$ & $\mathrm{SS}$ & $\mathrm{S}$ & $\mathrm{S}$ & $\mathrm{NS}$ \\
Additives & & $\mathrm{S}$ & $\mathrm{NS}$ & $\mathrm{NS}$ \\
Times*additives & & $\mathrm{NS}$ &
\end{tabular}

In columns, means followed with different letters express the meaningful effect of the additives at each fermentation times

NS: Not significant $(\mathrm{P}>0.05) \mathrm{S}$ : Significant $(\mathrm{P}<0.05)$ 
P. B. AGBOBATINKPO et al. / Int. J. Biol. Chem. Sci. 6(3): 1281-1292, 2012
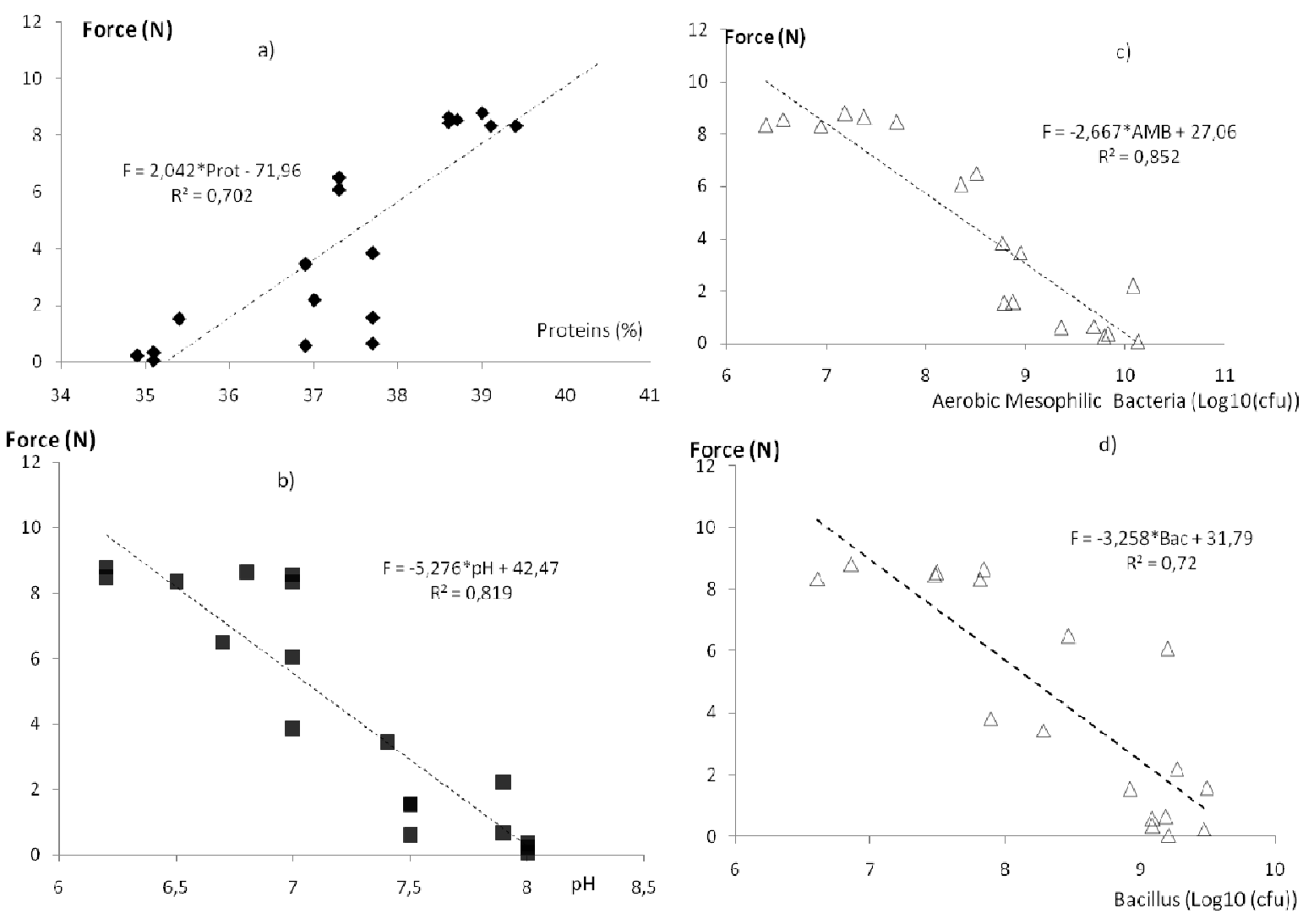

a) Proteins; b) pH; c) Aerobic Mesophilic Bacteria; d) Bacillus

Figure 1: Relationships between Compression Forces and selected microorganisms and physico-chemical parameters. 
High Bacillus spp. count during African locust beans fermentation was reported by many authors (Ouoba et al., 2004; Azokpota et al., 2006; Oladunmoye, 2007). Concerning Staphylococcus spp. count, our results were consistent with Azokpota et al. (2006) who reported that Staphylococcus spp. counts in Iru and Sonru increased sharply at the early stage $(0-18 \mathrm{~h})$ of the fermentation. However, we observed an upward trend after $18 \mathrm{~h}$ in contrast to previous work (Azokpota et al., 2006). Staphylococcus spp in fermented condiment of African locust beans could be originated from the contamination of environment (skin, clothes of producer, seeds) during the process but they did not appear to play any major role in the fermentation (Omezuriuke, 2008). However, further investigation is needed to identify species of Staphylococcus.

As far as texture is concerned, the lower value of compressing and penetrating forces obtained for cotyledons fermented with additives (weak firmness) agreed with Agbobatinkpo et al. (2011) who reported, based on the producers' opinion, that Ikpiru and Yanyanku play a role in the softening of the cotyledons during the fermentation of ALB to produce Sonru and Iru. This effect can be explained considering two hypotheses: Indeed, during Ikpiru and Yanyanku preparation, producers add Капти $(1: 5 \mathrm{w} / \mathrm{w})$ and ash concentrated filtrate (about $0.5 \mathrm{~g} / \mathrm{mL}$ ), respectively (Agbobatinkpo et al., 2011). Капти known also as Kanwa is a naturally occurring alkaline rock salt, mainly composed of sesquicarbonates containing various elements such as $\mathrm{Ca}, \mathrm{Fe}, \mathrm{S}, \mathrm{Cl}, \mathrm{Si}, \mathrm{P}, \mathrm{K}$ and Al. Kanmu is used in West and Central Africa as a tenderiser to reduce the cooking time of beans and other foods (Eyzaguirre et al., 2006). Thus, the higher softening of cotyledons fermented with Yanyanku or Ikpiru could be explained by the tenderiser effect of additives due to kапти or ash used during their processing. However, this assumption should be put into perspective since any significant correlation is established between ash content and compression force. Furthermore, additives contain Bacillus species and it is likely that the higher softening of fermented cotyledons was facilitated by the growth of Bacillus spp. This is consistent with the high and negative correlation between compression force and Bacillus count ( $\mathrm{r}=-0.85$, Figure 1). This observation was done earlier for samples with additives compared to those without additives. Indeed, Bacillus count reached its maximum value at 12 and $18 \mathrm{~h}$ of fermentation for samples with additives, whereas the maximum Bacillus count for samples from the fermented cotyledons without additives was reached at $24 \mathrm{~h}$ of fermentation.

The increase in $\mathrm{pH}$ during African locust bean fermentations was in agreement with previous findings reported by Pelig-Ba (2009) who mentioned that the increase in $\mathrm{pH}$ was more pronounced in the last days of fermentation than at the beginning. The increase of $\mathrm{pH}$ for fermenting mash of Anyi (fermented Samairea saman beans) from 5.5 to 8.0 at the end of fermentation is also reported by Omezuruike (2008). This increase is attributed to the deamination which causes conversion of the amino acid in the fermented material where ammonium ion is released and causes increasing of the $\mathrm{pH}$ of the medium (Berg et al., 2006; Pelig-Ba, 2009). The desintegration phenomenon could cause softening of the ALB, suggesting the highly significant and negative correlation between compression force and $\mathrm{pH}$ values $(\mathrm{r}=-0.91)$. Furthermore, the decrease in proteins content throughout the fermentation period is reported in previous work on Afitin condiment (Azokpota et al., 2006). This could be due to the leaching of soluble proteins since baskets are used to drain off 
water from the cotyledons during fermentation (Azokpota et al., 2006). This also could be related to protein degradation by Bacillus spp during the fermentation and the releasing of derived soluble amino acids such as glutamic acid (Odunfa, 1985).

The increase in fat content during African locust bean fermentation was consistent with Pelig-Ba (2009) and Azokpota et al. (2006).

As far as ash content is concerned, our results were consistent with Omafuvbe et al. (2004) who reported that fermentation seemed to increase the ash content of African locust bean seed by about $30 \%$ after fermentation. The low value of ash content obtained at $0 \mathrm{~h}$ fermentation time was earlier observed by Pelig-Ba (2009) who reported that the primary ash content before the fermentation process is generally low, less than $2 \%(\mathrm{db})$.

The role of Yanyanku and Ikpiru used for the fermentation of African locust bean seeds to produce food condiments is related essentially to the softening of fermented cotyledons, accordingly with the low values of compression of samples fermented with additives compared with the control. Correlations between compression force and selected physico-chemical parameters and microbial count suggest tentative factors among which Bacillus species presumably impacted, since these additives are their potential stock. However, the conditions of optimum efficacy of the additives need to be investigated.

\section{ACKNOWLEDGEMENTS}

The authors wish to thank the University of Abomey-Calavi and Aires-Sud project for their financial support.

\section{REFERENCES}

Achi OK. 2005. Traditional fermented protein condiments in Nigeria. Afr. J. Biotechnol., 4(13): 1612-1621.

Agbobatinkpo BP, Azokpota P, Akissoe N, Kayodé P, Da Gbadji R, Hounhouigan JD. 2011. Indigenous perception and characterization of yanyanku and ikpiru two functional additives for the fermentation of African locust bean. Ecol. Food. Nutr., 50: 101-114.

AOAC. 1984. Official Methods of Analysis of the Association of Official Analytical Chemists. AOAC: Washington.

Azokpota P, Hounhouigan DJ, Nago CM. 2006. Microbiological and chemical changes during the fermentation of African locust bean (Parkia biglobosa) to produce Afitin, Iru and Sonru, three traditional condiments produced in Benin. Int. J. Food Microbiol., 107: 304309.

Azokpota P, Mélaine SE, Houndenoukon, DJ, Hounhouigan, Mathurin C, Nago, Mogens J. 2011. Evaluation of yanyanku processing, an additive used as starter culture to produce fermented food condiments in Benin. J. Food Proc. Preserv., 35(6): 813-821.

Berg JM, Tymoczko JL, Stryer. 2006. Biochemistry $\left(6^{\text {th }}\right.$ edn). WH Freeman and Company: New York.

Chadare FJ, Gayet DP, Azokpota P, Nout MJR, Linnemann AR, Hounhouigan JD, van Boekel MAJS. 2010. Three traditional fermented baobab foods from Benin: Mutchayan. Dikouanyouri and Tayohounta: preparation properties and consumption. Ecol. Food. Nutr., 49: 119.

Eyzaguirre ZR, Nienaltowska K, de Jong LEQ, Hasenack BBE, Nout RMJ. 2006. Effect offood processing of pearl millet (Pennisetum glaucum) IKMP-5 on the level of phenolics, phytate, iron and zinc. J. Sci. Food Agric., 86: 1391-1398. 
Gutierrez ML, Maizi P, Nago CM, Hounhouigan DJ. 2000. Production et commercialisation de l'Afitin dans la région d'Abomey-Bohicon au Bénin. CERNA, CNEARC, CIRAD. Librairie de CIRAD, p. 124.

Herigstad B, Hamilton M, Heersink J. 2001. How to optimize the drop plate method for enumerating bacteria. J. Microbiol. Methods, 44(2): 121-129.

Ismail A, Ikram MKE, Nazri MSH. 2008. Roselle (Hibiscus sabdariffa L.) seeds nutritional composition, protein quality and health benefits. Food, 2(1): 1-16.

Nout MJR, Rombouts FM, Havelaar A. 1989. Effect of accelerated natural lactic fermentation of infant food ingredients on some pathogenic microorganisms. Int. J. Food. Microbiol., 8: 355-361.

Odunfa SA. 1985. African fermented foods. In Microbiology of Fermented Food, (vol 11). Wood BJB (ed). Elsevier Appl. Sci. Publ.: Amsterdam; 155-191.

Oladunmoye MK. 2007. Effects of fermentation on nutrient enrichment of locust beans (Parkia biglobosa, Robert bam). Research. J. Microbiol., 2(2): 185189.

Omafuvbe BO, Falade OS, Osuntogun BA, Adewusi SRA. 2004. Chemical and biochemical changes in african locust bean (Parkia biglobosa) and melon (Citrullus vulgaris) seeds during fermentation to condiments. Paki. J. Nutr., 3(3): 140-145.

Omafuvbe BO, Shonukan OO, Abiose SH. 2000. Microbiological and biochemical changes in the traditional fermentation of soybean for "soy-daddawa" - nigerian food condiment. Food Microbiol., 17: 469-474.
Omezuruike O.J. 2008. Microbiological studies on the production of anyi, a potential condiment made from laboratory fermentation of Samanea saman (Monkey pod) seeds (Jacq Merr). E.J.E.A.che., 7(10): 3486-3504.

Ouoba LI, Diawara B, Amoa-Awua WK, Traoré AS, Moller PL. 2004. Genotyping of starter cultures of $B$. subtilis and B. pumilus for fermentation of African locust bean (Parkia biglobosa) to produce Soumbala. Int. J. Food. Microbiol., 90(2): 197-205.

Parkouda C, Diawara B, Ouoba LI. 2008. Technology and physico-chemical characteristics of Bikalga. alkaline fermented seeds of Hibiscus sabdariffa. Afr. J. Biotechnol., 7(7): 916-922.

Pelig-Ba KB. 2009. Effect of Ash. KOH and millet on the fermentation of Parkia biglobosa seeds to form a Condiment. Pak. J. Nutr., 8(10): 1548-1554.

Sarkar PK, Morrison E, Tinggi U, Somerset SM, Craven GS. 1998. B-group vitamin and mineral contents of soybeans during kinema production. J. Sci. Food Agric., 78: 498-502.

Sneath HP. 1986. Endospore-forming Grampositive rods and cocci. In Bergey's Manual of Systematic Bacteriology, Sneath HP, Mair SN, Sharpe ME, Holt GJ (eds). Williams \& Wilkins : USA; 1104-1139. 